\title{
Bruce Balfour Junor and the Enduring Mystery of the Proceedings on the East Mole at Dunkirk in 1940
}

\section{Brian Jeffrey Street}

Le capitaine de frégate James Campbell Clouston, un Canadien de Montréal, a rejoint les rangs de la Marine royale britannique en 1918 parmi les cadets recrutés grâce au système "special entry ».Au cours des années, il a accédé au rang d'officier d'artillerie navale, pour ensuite assumer le commandement du contre-torpilleur HMS Isis en 1937. Le navire ayant été endommagé pendant la campagne de la Norvège, Clouston fut envoyé au port de Dunkerque, où il fut nommé officier responsable de la jetée de l'Est lors de l'évacuation des Alliés. La présente note étudie les occasions ratées de recueillir des renseignements indispensables d'un important témoin oculaire concernant le rôle de Clouston dans cet événement historique.

\section{Introduction}

Walter Lord concluded that the best time to talk with individuals about their part in an historical event was twenty-five years later. "Enough time has gone by to have perspective, the bitterness has worn off if things went badly, but not so much time has passed so that people have begun to invent," he reasoned. ${ }^{1}$

His account of the Allied evacuation from Dunkirk, The Miracle of Dunkirk published in 1982, pushed that margin by almost two decades. According to Lord, he needed about four years to finish the project. Nevertheless, he was fortunate in finding many veterans whose memories were still fresh. Like every other historian interested in the subject, he could also draw on the large body of official reports that were written and submitted-typically within days-by those who were there. Lord's remains one of the better books devoted to the story. He had a good instinct for finding and relating small details that gave an in-the-moment feel to his narrative. The depth of his research is reflected in the collection of his papers now

\footnotetext{
1 Jenny Lawrence, ed., The Way It Was: Walter Lord on His Life and Books (New York: Jenny Lawrence, 2009), 207.
}

The Northern Mariner / Le marin du nord, XXX, No. 3 (Fall 2020), 291-300 
held by the Imperial War Museum in London. ${ }^{2}$

Richard Collier's The Sands of Dunkirk also relied extensively on first person accounts. Those were intended to convey the story as "a human experience"-one reconstructed by the author, according to copy on the book's dustjacket, "based on exhaustive research and hundreds of interviews in England, France and Germany."3 Indeed, Collier or his researchers interviewed roughly a thousand individuals for the book. Of course, not every story they uncovered was included in his final manuscript.

One man who was an important eyewitness to events on the east mole at Dunkirk was overlooked by Lord and almost ignored in Collier's account. Had Lord known about Bruce Balfour Junor, he likely would have tracked him down and listened to what he had to say. Moreover, it is almost certain he would have woven Junor's experiences into key episodes.

It is difficult to understand why Collier chose to mention the former Royal Navy officer only briefly - and, for that matter, why he failed to interview him at length. A researcher's summary of a conversation with Junor, which occurred in the spring of 1960, amounts to just two double-spaced typed pages. ${ }^{4}$ Yet Junor was in a position to offer insights that few other individuals could match, slightly shy of two decades after his part at Dunkirk. Walter Lord might have seen that as an opportunity worth pursuing, even if it fell short of his estimate of the ideal time to

2 The fate of Lord's Dunkirk papers is a story on its own. According to Jenny Lawrence, Lord bequeathed the rights to his books to Gilman, his high school in Baltimore (The Way It Was, 282). An email sent to an archivist at the school's library in 2017 led to correspondence with a curator at the Imperial War Museum (IWM) at Duxford, who confirmed that ten boxes of material donated by Lord or his estate were held in London. They included notes, correspondence and research materials used in the writing of The Miracle of Dunkirk. The curator provided reference numbers, 67/348/1-5 and $67 / 357 / 1-5$, and a summary of how the papers were constituted. This was enormously helpful to the author's research and greatly appreciated, given that at the time Lord's papers were not publicly listed as part of the IWM's collection. However, while preparing this research note, the author discovered that the IWM has since made object details for the "Private Papers of W Lord" findable through its website and assigned those a new catalogue number, Documents.24840. In addition, there are now eleven boxes of material, not ten. Efforts to learn how the papers might have been reorganised and which citation to use have been thwarted by limited access to the IWM and closures in effect due to Covid-19.

3 Richard Collier, The Sands of Dunkirk (London: Collins, 1961).

4 Collier's Dunkirk related papers are also at the IWM, although the same curator who gave the author details regarding Walter Lord's papers indicated they were among a set that covered several of his books. He further advised, "Tell your researcher to ask for the papers...giving the reference 63/5/1-17 but just the boxes on Dunkirk." In hindsight, that should have alerted the author, whose London based researcher later reported the material was "poorly labelled." She added regarding the Dunkirk material: "Collier's papers were arranged very simply with four boxes of interviews and narratives in strict alphabetical order. Boxes were $\mathrm{a}-\mathrm{d}, \mathrm{e}-1, \mathrm{~m}-\mathrm{r}$ and $\mathrm{s}-\mathrm{z}$. There were also two boxes of miscellaneous papers." Like Lord's papers at the IWM, the "Private Papers of Richard Collier" are now findable through the museum's website. They, too, have a new object number, Documents.18909, and the collection has evidently grown from seventeen boxes to thirty-three. Attempts to learn which part numbers now pertain to The Sands of Dunkirk have so far not produced results. And, it has not been possible to visit the IWM to obtain clarification directly. 
interview a witness.

Junor sat for at least one other interview with an author, although the details of when and where that occurred are not known. Only published excerpts are available. All that is significant in the context of a fundamental question about James Campbell Clouston, pier master of the east mole and the subject of a biography this author is preparing. After all the years that have passed, why is so little known about his actions? How is it possible that even today, more than eighty years later, one of the most important figures in such an epic event remains largely a mystery?

The answer starts, of course, with the tragedy of his death in the English Channel while returning to Dunkirk during the latter days of the Allied evacuation. He did not live to provide his own version of what happened

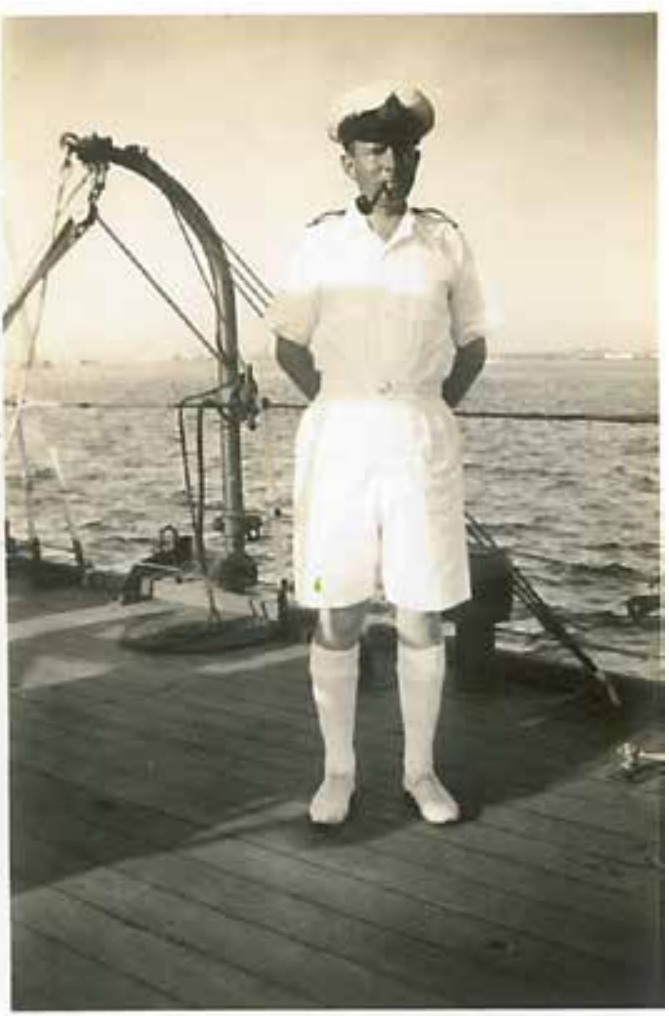

LCdr Bruce Balfour Junor (Source: the family) on the mole over six days and nights in late May and early June 1940. As a result, historians have given him scant attention or not bothered to mention him at all. ${ }^{6}$ But Lieutenant Commander Bruce Balfour Junor, who was one of the officers in Captain Tennant's naval shore party that went to Dunkirk on 27 May and worked alongside Clouston for almost the entirety of his time there, could have filled in many of the missing pieces of the puzzle - if only someone had shown enough interest and invested the time and effort needed to glean more of a day-to-day account and nail down some key facts. Instead, we are left to construct a narrative from reports of proceedings for ships that went alongside the mole-some of which mention Clouston-along with a few recollections in letters or published articles and books, and other archived sources.

\footnotetext{
5 Clouston drowned after an RAF seaplane tender he was in was attacked and sunk by enemy aircraft on 2 June.

6 This author surveyed twenty-five leading works about Dunkirk. Clouston appears at least once in seventeen of those, and is most often referred to as J. C. Clouston. Only two of the titles referred to him as Campbell, including a corrected version of Lord's The Miracle of Dunkirk. He was identified as Jack Clouston in the book's initial run. Many other authors have made similar errors. Titles consulted refer to him as Jack, James or John.
} 
"The full story of Dunkirk will never be told," warned A.D. Divine in his detailed first chronicle of the evacuation. ${ }^{7} \mathrm{He}$ was there to witness enough of what happened but also had a reporter's instincts - if not also an historian's reflexes to understand what is needed to provide a complete account. Even so, it is hard to accept that an aspect of one of the key events of the $20^{\text {th }}$ century has never been properly examined and might remain so due to a lack of evidence. It is truly unfortunate that Junor didn't tell us more of what he knew before he died in March 1999 in Sheffield, England.

\section{Junor's Service Record}

So, who was Bruce Balfour Junor, and what did he have to say about his experiences on the mole with Campbell Clouston? He was born on 22 April 1901 in Bristol. Both his parents were from Glasgow. The 1911 census indicates his father was a successful timber broker (there were two domestics living with the family) and that young Bruce had two older sisters. A family tree on Ancestry indicates he also had another sister, two years younger, who died at age six. ${ }^{8}$

For reasons unknown, Bruce Junor decided to join the Royal Navy and entered the service as a special entry cadet in June 1919. ${ }^{9}$ This was a somewhat confusing period for the tenth term of cadets, which followed Clouston's. The term started in April 1919 and reported to the Royal Naval College at Keyham, but was interrupted several times as new cadets and those from elsewhere-including Junor-came and went. ${ }^{10}$

Comments in Junor's service record are generally favourable. He was regarded as trustworthy, quiet and self-reliant. It was noted that he had a smart appearance and excelled athletically. Evidently, he was a good long distance runner. In December 1924, several months after reaching the rank of lieutenant, Junor married. A year later, his wife Nora gave birth to a daughter they named Faith. Marriage and fatherhood soon dulled his interest in any further service abroad; and indeed, his service record reflects a lack of activity afterwards, perhaps as a result. He was promoted to lieutenant commander in August 1932, by which time he had qualified for command of a destroyer, but it is unclear whether he ever received such an appointment.

We do know that from the end of May 1937 to likely the outbreak of the Second World War, Junor was first officer on the light anti-aircraft cruiser HMS Coventry. ${ }^{11}$ On New Year's Day 1940 while serving with the Home Fleet, the ship was damaged

7 A. D. Divine, Dunkirk (London: Faber \& Faber, 1945), 7.

8 “Ancestry.ca - 1911 England Census," accessed 5 February 2021, https://www.ancestry.ca/ imageviewer/collections/2352/ images/rg14_15071_0547_03

9 "Bruce Balfour Junor" (n.d.), The National Archives, Kew, (TNA), ADM 196/149/78.

10 John H Beattie, The Churchill Scheme: The Royal Navy Special Entry Cadet Scheme 1913-1955 (Privately published: np, 2010), 40.

11 "Navy Lists, Monthly, 1939, August - British Military Lists - National Library of Scotland," accessed 5 February 2021, https://digital.nls.uk/british-military-lists/archive/92706234. 
in a German air attack on the Shetland Islands. ${ }^{12}$ Later, in May Coventry took part in operations as part of the Norway campaign (where, incidentally, she was again damaged after running aground and had to return to the UK for repairs), but by mid-April Junor had already transferred to the light cruiser HMS Ajax. ${ }^{13}$ The ship was still undergoing a refit at Chatham Dockyard after seeing action near the end of the previous year in the Battle of the River Plate. ${ }^{14}$ It is not long after that when Junor himself relates how he ended up as part of Captain Tennant's naval party assigned to oversee the evacuation of Allied troops from France, which is the start of his largely untold account of working alongside Campbell Clouston on the east mole at Dunkirk.

\section{The Interviews}

It is not known how Richard Collier found Bruce Junor, but in the author's papers at the Imperial War Museum there is a handwritten letter from Junor, dated 14 February 1960, in which he indicated: "Naturally I shall be only too pleased to give what help I can, but it is a long time ago and I am afraid I have forgotten most of it all." ${ }^{15} \mathrm{He}$ added that he had a small poultry farm in Benenden, Kent, and seldom left the place. Any afternoon would be suitable for a visit. He suggested a telephone call first. Collier sent Pamela Sargent, one of his researchers, to meet Junor. There is no date of her interview on her typed notes. They are recorded as simply "Reports of Interviews - No. 111." Below that is "Lieutenant Commander BRUCE BALFOUR JUNOR."16

Junor sent a follow-up note to Sargent, dated 16 May. Their conversation had stirred some memories. "The other day I thought of something else about Dunkirk," he wrote. He hoped he wasn't wasting her time. "About a mile and a half from the end of the jetty and to the eastward a medium-sized merchant ship, about 7,000 tons I would say...was already sunk in shallow water with her decks about awash but her top...well clear so that she must have appeared from the air to be afloat. Anyway the enemy aircraft expended an enormous amount of time, energy and material on the wreck, which would otherwise have been poured out on us."17 Clearly, Junor's memory wasn't as bad as he had suggested.

His experiences on the mole were also related in part by the historian and

\footnotetext{
12 "HMS Coventry (D 43) of the Royal Navy - British Light Cruiser of the Ceres Class - Allied Warships of WWII - Uboat.Net," accessed 5 February 2021, https://uboat.net/allies/warships/ ship/1198.html.

13 "Navy Lists, Monthly, 1940, May - British Military Lists - National Library of Scotland," accessed February 5, 2021, https://digital.nls.uk/british-military-lists/archive/92776854.

14 "HMS Ajax (22) of the Royal Navy - British Light Cruiser of the Leander Class - Allied Warships of WWII - Uboat.Net," accessed 5 February 2021, https://uboat.net/allies/warships/ship/4002.html.

15 B.B. Junor to Mr Collier, 14 February 1960, IWM, London, presumably Box e - 1, Dunkirk Book, private papers of Richard Collier, Documents.18909 (Collier Papers).

16 Dunkirk 1940, Reports of Interviews - No. 111, Lieutenant Commander Bruce Balfour Junor, (Junor interview) (n.d.), Collier papers.

17 B.B. Junor to Miss Sargent, 16 May 1940, Collier papers.
} 
author Max Arthur, who died in 2019 at the age of 80. Among his many works of oral histories, Arthur produced The True Glory: The Royal Navy 1914-1939 (London: Hodder \& Stoughton, 1996), and The Navy: 1939 to the Present Day (London: Hodder \& Stoughton, 1997). These were followed by a combined and edited volume entitled Lost Voices of the Royal Navy (London: Hodder \& Stoughton, 2005), and then an ebook version in 2012. Junor was included in the 1997, 2005 and 2012 editions, with short and longer versions of his recollections (approximately 350 and 1,500 words). Efforts to find Arthur's original taped recordings or transcripts have so far not produced results. Still, from what Collier's researcher reported and Arthur's published accounts reveal, we can piece together enough of Junor's story to shed more light on what happened on the mole-and wish that more effort had gone into coaxing details out of his foremost memories.

\section{On the East Mole}

Here is what Junor remembered. Overall, Arthur's retelling has the benefit of it being an edited transcript (one is simply an abridged version of the other), although there are lapses in Junor's memory, whereas Collier's researcher provided a summary. That said, she recorded several anecdotes that have never appeared in print.

To Arthur, Junor explained that he was on a short leave when he received a telephone call and was ordered to report at once with his boots and gaiters on, ready to sail. "I dashed back to Chatham, where I and another officer went in an Admiralty car to Ramsgate and boarded an old destroyer, HMS Wolfhound," 18 he recalled. In fact, Wolfhound was at Dover. However, it is interesting that Junor mentioned he was accompanied by another officer. Not all of those in Tennant's naval party have been identified, which is a separate mystery this author has attempted to solve. Part of the difficulty in naming the officers is a discrepancy in the number who reportedly went. Tennant said he took twelve officers along with 160 ratings, while others have suggested there were eight officers (and fewer other ranks). Including Clouston, seven of the officers - all commanders - in Tennant's party are known, and another, Cdr Michael Ellwood, who was a signals officer, was likely counted, as well. Junor adds to the total, and evidence suggests there were at least two other lieutenant commanders. All that to say, it would have been helpful if Arthur had stopped Junor to ask: "Do you remember the other officer's name and rank?"

For the benefit of Collier, Junor was more specific about one point. He indicated that he was on a weekend's leave in Chatham. If that was cut short, it suggests he reported to Dover on Sunday, 26 May 1940. Wolfhound left for Dunkirk the next day. Junor accurately recalled that while crossing the Channel on the afternoon of the $27^{\text {th }}$ Wolfhound came under repeated air attacks by Stuka dive bombers, which were evaded by deft manoeuvring. It was also true, as he described, that conditions

18 Max Arthur, Lost Voices of the Royal Navy (London: Hodder \& Stoughton, 2012), 226. 
at Dunkirk were horrific when they landed. He told Collier's researcher "the town was burning and most of the harbour facilities were in ruins and there seemed to be continuous bombing attacks." ${ }^{19}$ He told Arthur, "I remember four of us went into a building in Dunkirk when a big bomb blasted off and a couple of soldiers who had been out in the open were killed, but inside the building we were alright." 20

Junor also recalled that soon after their arrival, Captain Tennant established a naval headquarters, which was separate from the French HQ at a bastion in the town, in a dugout at the shore end of the east mole. This was likely an existing structure related to a nearby canal lock. With the harbour essentially destroyed and unusable, it was decided to bring ships alongside the mole and evacuate soldiers from there. "I was part of a small group of naval officers who were ordered to report to the jetty," Junor explained to Arthur. "For the next forty-eight hours, I was never off my feet," he added. ${ }^{21}$

Again for Collier, he provided more details. He explained that "together with Commander J. C. Clouston, who had been appointed pier master, he was sent about half a mile along the jetty. They had a supply of bully beef and biscuits, not forgetting a bottle of rum. Before long the men came marching down the jetty and for him the evacuation had begun, keeping him on his feet continuously that night, all the next day and night, when he managed to get half an hour's sleep."22

Junor described for Collier how enemy aircraft were kept "more or less at bay" by a French Bofors battery on the west mole, which was closer to the oil refineries that were ablaze and casting a dark pall of thick smoke over Dunkirk. Nevertheless, enemy shellfire and incessant bombing made their work of loading men into waiting ships more challenging. The mole took several hits and had to be repaired with gangways laid across the gaps.

For both authors, he recalled the difficulties associated with tides. Dutch "skoots," which were shallow draft vessels designed to carry cargo in inland waterways, were able to navigate closer to the shore end of the mole, while larger vessels such as destroyers could only safely reach about midway along. "The trouble was the range of the tide was eighteen feet," Junor told Arthur, "making it very difficult to get the troops down into the barges at low water." He added: "Very early on, the Admiral in charge [of Operation Dynamo, as the evacuation was known, Vice Admiral Bertram Ramsay in Dover] had sent a signal asking for scaling ladders. Chatham and Sheerness dockyards worked day and night making dozens of skoot scaling ladders to send over to Dunkirk in destroyers." ${ }^{23}$ Elsewhere along the mole, ships improvised when necessary. As photographs of the evacuation attest, simple planks and ladders of all types were used at various times.

19 Junor interview, Collier papers.

20 Arthur, (2012), 227.

21 Ibid.

22 Junor interview, Collier papers.

23 Arthur, (2012), 227 - 8. 
"We were at it twenty-four hours a day, getting these chaps off with very little food," Junor explained to Arthur. "After the first forty-eight hours, other chaps working with me simply lay down on the jetty and went to sleep with his head on his cap. He slept for about fifteen minutes, then got up, didn't feel much better and said, 'You go and have a sleep.' I lay down on the concrete and put my cap under my head and slept like a log for about fifteen minutes. What those fifteen minutes did for me was quite incredible. I don't remember any food other than a sandwich at times, and, on occasion, being able to scrounge some food off ship whilst the soldiers were boarding." 24

In the longer of the Arthur accounts, Junor related that he was on the mole "about a week" - it could not have been that long, even if it seemed it did-when he was shanghaied. "I had been helping a wounded soldier down into a trawler when the bombing increased with a bomb landing close by, so the skipper thought it best to go and pulled away once I was on board," he said. "A bomb immediately

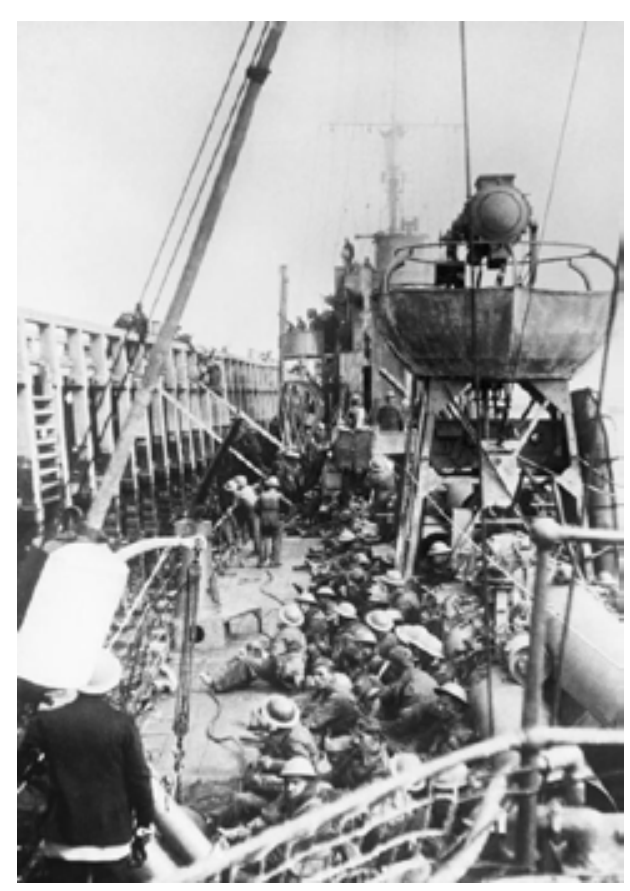

British troops boarding the destroyer HMS Vanquisher at low tide from the Mole at Dunkirk, using scaling ladders

(Source: Imperial War Museum, HU1153) fell where I had been standing on the jetty." 25 Junor didn't say where Clouston was at the time.

"I found myself in Ramsgate," he continued. "I went to a hotel the Admiralty had taken over, which was packed out. I slept in a chair, wrote a hurried note to my wife and bought a pair of socks before getting a lift back to Dunkirk in HMS Keith. I did this on my own initiative, as I had involuntarily deserted my post. I was there some days more feeling very weary and my feet were sore [from] going up and down that concrete." 26

He gave a slightly fuller version of the story to Collier's researcher. "The difficulties of dealing with the troops unaccustomed to the sea and ships and exhausted beyond imagination were enormous," she reported. "Many of the smaller craft were about twelve feet below the top of the jetty. It was as he assisted troops in doing this jump by being on the deck below and calling up to them to jump [when] the small trawler suddenly pushed off and before he could

24 Ibid., 228.

25 Ibid.

26 Ibid. 
do anything about it was on his way to Dover [sic]."27

Junor also said that when he returned to Dunkirk, Clouston greeted him warmly. "Glad to see you back, old boy," he said. "They laughed when he told of being shanghaied by the skipper of a trawler." ${ }^{28}$ This was an example of Clouston's reputation for humour and calmness throughout his time on the mole.

It helps, too, when Junor relates how conditions improved somewhat around that time. He and others on the seaward end of the mole slept during the day on the hard concrete and food was more easily scrounged from incoming vessels, according to the report prepared for Collier. "He remembers many a good lunch in a first-class saloon together with some British officers whose heads kept dropping into their soup [from] exhaustion." 29

From the report, we can infer he was recalling events on or about 1 June. "At dawn the next day, together with Clouston and the rest of their small party," Collier's researcher wrote, "they got into a landing craft and steered for home, to be picked up by a paddle minesweeper Whippingham at once, abandoning their landing craft." ${ }^{30}$ The details were close to the actual facts. Still, Junor's memory could have helped clarify a lingering misconception. Contrary to most published accounts, Clouston did not return to Dover on 1 June to enjoy a meal, good washing up, and a night's rest before meeting Vice Admiral Ramsay at Dover Castle the next day. It's not clear where that version originated, but as records clearly show Clouston left Dunkirk in the early hours of 2 June. We know from a letter sent later to Clouston's widow that he worked until the last moment and refused to risk another ship to take his small naval party to safety. ${ }^{31}$ In fact, he had already commandeered a motor landing craft, MLC 22, the night before. Shortly before dawn, at 0330 or so, he and his party boarded the craft and steered for the coast of England.

They quickly ran into trouble. The craft was difficult to pilot, they discovered. It was also not degaussed as a defence against magnetic mines in the Channel, which worried Clouston. But they were soon spotted by HMS Portsdown, an old requisitioned paddle steamer making its way back to England loaded with troops. Clouston and his party transferred to the ship, and MLC 22 was scuttled. ${ }^{32}$ To his horror, Clouston learned that Portsdown had no degaussing equipment, either. At that point, he was too tired to care, and he went below to the master's cabin for a few hours of sleep. ${ }^{33}$

\footnotetext{
27 Junor interview, Collier papers.

28 Ibid.

29 Ibid.

30 Ibid.

31 Cdr V.N. Surtees to Gwyneth Clouston, 15 June 1940, Clouston family papers (private collection), Courtesy of Dane Clouston, file Family - Campbell 2.

32 "Report by C/J93893 C.P.O. H. Mitten" (n.d.), TNA, ADM 199/791, 137.

33 Sublieutenant Richard H. Church, "Report H.M.S. 'PORTSDOWN' (Dunkerque)" (n.d.), TNA, ADM/788A, 67-69.
} 
Portsdown arrived at Ramsgate by mid-morning. ${ }^{34}$ Somehow, Clouston hurried to meet with Ramsay and others at Dover Castle, leaving Junor behind. Soon after, a signal was sent to Captain Tennant that Clouston was returning with a plan for that evening's evacuation of French troops. ${ }^{35}$ Within hours, two RAF seaplane tenders were made available for Clouston and his party, which included some French officers and NCOs.

So much for a "good night's rest" or other comforts in the time between leaving Dunkirk and returning to the embattled coast of France, sometime between 1430 and 1630 (records vary with regard to the precise time he left Dover). Clouston enjoyed, at most, a few hours' sleep and was under some pressure again before setting out on his fateful crossing.

\section{Conclusion}

Like many veterans, Bruce Junor did not speak much about the war afterwards - at least, not around his family. Yet, he had received a mention in despatches for his role at Dunkirk. ${ }^{36}$ There is no public record of his service after that, although evidence suggests he saw duty aboard submarines. By the war's end, he reached the rank of acting commander. In 1946, he was honoured with an OBE in recognition of "distinguished services during the war in the Far East." ${ }^{37}$ Recently a granddaughter remembered, "Grandpa, [like] so many of his peers, was very reluctant to talk about his war experiences. It was not until I was in my thirties that I even realised... he had been awarded an OBE." 38

Had he spoken more-or if he was asked more probing questions - he might have shared further details of what he knew. We might have learned from him exactly what Captain Tennant said to his officers during their crossing from Dover to Dunkirk on 27 May, for example, which is relevant given suggestions that some roles during the evacuation were determined then. We might have a better idea of how and when the decision was made to use the east mole to evacuate troops. There are details about how Clouston and his party communicated with the shore end of the mole and the organising of troops there that remain unanswered. And, we might gain further insights into Clouston's personality. The few, hitherto unpublished anecdotes and bits of dialogue Junor provided are intriguing. We can only wish there were more of them.

\footnotetext{
34 John de S. Winser, BEF Ships Before, At and After Dunkirk (Gravesend, Kent: World Ship Society, 1999), 95 .

35 W. J. R. Gardner, ed., The Evacuation From Dunkirk: 'Operation Dynamo' 26 May - 4 June 1940 (London \& New York: Routledge, 2000), 192.

36 Supplement to The London Gazette (16 August 1940), accessed February 5, 2021, https://www. thegazette.co.uk/London/issue/34925/page/5068/data.pdf.

37 Supplement to The London Gazette (11 June 1946), accessed February 5, 2021, https://www. thegazette.co.uk/London/issue/37603/supplement/2882.

38 Karen Anderson, email to the author, 15 August 2020. Anderson's mother was Faith Balfour Woodmansey (née Junor), Bruce and Nora Junor's only child.
} 